\title{
OLVASÓKÖRÖK SZEREPE A MESTERSÉGES INTELLIGENCIÁVAL KAPCSOLATOS ATTITÜDÖK FORMÁLÁSÁBAN - MÓDSZERTANI JAVASLAT ASIMOV ROBOT-TÖRTÉNETEIRE REFLEKTÁLÓ VITAKLUBOK SZERVEZÉSÉVEL KAPCSOLATBAN
}

Szerző:

Mező Ferenc (PhD)

Eszterházy Károly Katolikus Egyetem

Szerző e-mail címe:

ferenc.mezo1@gmail.com

\section{Lektorok:}

\author{
Simó Ferenc Zoltán (Dr. Jur.) \\ Eszterházy Károly Katolikus Egyetem \\ Szabóné Balogh Ágota (Ph.D.) \\ Gál Ferenc Egyetem
}

...és további két anonim lektor

\begin{abstract}
Absztrakt
Jelen tanulmány az olvasókörök mesterséges intelligenciával (MI-vel) kapcsolatos szemléletformálásban betöltött szerepére fókuszál. Központi kérdése: Hogyan szervezhetünk MI-vel kapcsolatos olvasóköröket. E tanulmány egy lehetséges olvasókör példafeladatait is tartalmazza, amely olvasókör Isaac Asimov robottörténeteit használja fel az MI-vel kapcsolatos szemléletformálásra.
\end{abstract}

Kulcsszavak: mesterséges intelligencia, olvasás, attitűd, Asimov

Diszciplina: pszichológia, pedagógia, irodalomtudomány

\begin{abstract}
THE ROLE OF READER CLUBS IN THE FORMING OF ATTITUDES ABOUT ARTIFICIAL INTELLIGENCE - METHODOLOGICAL PROPOSAL FOR THE ORGANIZATION OF DISCUSSION CLUBS REFLECTING ASIMOV'S ROBOT STORIES

The present study focuses on the role of readers clubs in the attitude forming about artificial intelligence (ai). Its central question is: how can we organize readers clubs about ai. This study also includes example tasks of a possible readers club that uses isaac asimov's robot stories for attitude forming about ai.
\end{abstract}

Keywords: artificial intelligence, reading, attitude, Asimov

Disciplines: psychology, pedagogy, literary studies 
Mező Ferenc (2021): Olvasókörök szerepe a mesterséges intelligenciával kapcsolatos attitűdök formálásában - Módszertani javaslat Asimov robot-történeteire reflektáló vitaklubok szervezésével kapcsolatban. Mesterséges intelligencia - interdiszciplináris folyóirat, III. évf. 2021/2. szám. 79-95. doi: 10.35406/MI.2021.2.79

Az attitűdök a tárgyukkal - esetünkben például a robotokkal, mesterséges intelligenciával (MI-vel) - kapcsolatos értékelő vélemények, amelyeknek három komponensét szokás megkülönböztetni (Allport, 1954); ezek:

1) Kognitív komponens: az attitűd tárgyával kapcsolatos ismeret, tudás. A robotok/MI témában közvetlen tapasztalat, oktatás, irodalmi, film- és játékélmények, véleménycserék következtében szerzett ismeretekről, illetve ezek alapján többékevésbé tudatos módon kikövetkeztetett ismeretek formálhatják e komponenst.

2) Affektív komponens: az attitűd tárgyával kapcsolatos érzelmi viszonyulás. Így például a robotokkal és tágabb értelemben a mesterséges intelligenciával kapcsolatban érzelmi töltését tekintve negatív (szorongással, undorral és/vagy agresszióval jellemezhető), semleges (érzelmi közönnyel jellemezhető) vagy pozitív (a téma iránti rajongással, akár szeretettel jellemezhető) attitűdről beszélhetünk.

3) Konatív komponens: az attitűd tárgyával - esetünkben: a robotokkal/MI-vel - kapcsolatos viselkedés, illetve viselkedési szándék.

E komponensek egyrészt az attitűdök diagnosztizálható elemei, másrészt az atti- tűdformálás (ezen belül: egy-egy attitűd konzerválásának, módosításának, konzerválása megakadályozásának, illetve módosulása megakadályozásának) célterületei is lehetnek. Az attitűdök feltárása és formálása során hasznosítható egyik lehetséges módszer a tárgyukkal kapcsolatos egyéni/csoportos beszélgetés - esetleg filmklubbal vagy olvasóköri foglalkozással egybekötve.

A filmek, irodalmi élmények a tanúlók érdeklődés felkeltésére általában véve is alkalmasak - a tanulók érdeklődésének felkeltésével kapcsolatban lásd: Nagy Lehocky (2008). Az MI téma felé ezeken túl színházpedagógiai (Bancsi és Mező, 2020) és múzeumpedagógiai (Mező és Mező, 2020) módszerekkel is közelíthetünk, és általában véve élménypedagógiai kontextusba helyezhetjük tárgyalását - az élménypedagógiával kapcsolatban lásd: Mező Katalin (2015) könyvét. Végül, de nem utolsó sorban az MI-vel kapcsolatos szemléletformáló, ismeretterjesztő tevékenységbe a robotprogramozási tevékenységek (Csernai, 2020), a robotokkal történő oktatás (Mező és Szabóné Burik, 2021) is fontos szerepet játszhat. Tágabb értelemben pe- 
dig az MI-t eszközként használó foglalkozások tartása is ide sorolható (v.ö.: Beták és Szabó, 2020; Szabóné Balogh, 2020; Tóth és tsai, 2021).

A mesterséges intelligenciával kapcsolatos attitűdök filmklubok szervezésén alapuló formálásával kapcsolatban Mező, Mező és Mező (2019) közöl módszertani tanácsokat (a tanulmány mellékeltében kétszáznál több robotokkal, MI-vel kapcsolatos játékfilm listája is szerepel). Jelen tanulmány további részében olvasóköri keretek között gondoljuk végig a robotokkal/MI-vel kapcsolatos attitűdformálás lehetőségeit, hozzátéve, hogy az olvasókörök foglalkozásai egyben a tárgyukkal kapcsolatos vitaklubok is lehetnek.

\section{Olvasókörök szervezése}

Az MI témával kapcsolatos attitűdformálást célzó olvasókör szervezésének általános lépései a következők:

\section{Az olvasókör elókésquitése}

1.1. Az olvasókör célcsoportjának meghatározása (életkor, előzetes tudás, olvasáshoz való viszony, MI témával kapcsolatos feltételezhető attitűd alapján például).

1.2. Az olvasókör céljának meghatározása (például cél lehet az MI témakörrel kapcsolatos ismeretterjesztés, a téves hiedelmek és a valós veszélyek, illetve hasznosítási lehetőségek tudatosítása).
1.3. MI témájú irodalmi művek listájának összeállítása. E lista esetében lényeges szempontok: a) az olvasókör tagjai számára elérhető, beszerezhető művek legyenek; b) a művek az olvasókör által ismert nyelven legyenek elérhetők; c) a művek az olvasókör várható tagjainak feltételezhető szókincséhez, előzetes tudásához illeszkedjenek (más művekre van például szükség egy olvasni éppen megtanult kisiskolások számára szervezett foglalkozás sorozat, és egy egyetemistákat célzó olvasókör esetében); d) a művek terjedelme (egy perces történet, novella, regény) is lényeges lehet.

1.4. Az olvasókör időbeli vonatkozásainak megtervezése: hány alkalommal találkoznak az olvasókör tagjai (egy tanévbeli félévben például kb. 13-15 alkalom valósítható meg), alkalmanként mennyi ideig tart egy foglalkozás (45-90 percet javaslunk), illetve egy foglalkozás időbeosztása miként fog alakulni?

1.5. Az olvasókör (tanterem, klubhelyiség, könyvtár, étterem, szabadtér, esetleg: online tér) helyszínének kiválasztása

1.6. Az olvasókör költségvetésének tervezése: várható kiadások (például az irodalmi múvek vagy kölcsönzésük ára, terembérleti díj, foglalkozásvezetők és meghívott vendégek tiszteletdija, étkeztetés költségei) és várható bevételek (részvételi díj, pályázati források, szponzoráció stb.), alakulásának áttekintése és az önkéntesek bevonásának meggondolása.

1.7. Az olvasókör meghirdetésének, a tagok toborzásának megtervezése, megvalósítása. Kiskorúak esetében a 
szülők/gondviselők írásbeli hozzájárulását is be kell szerezni azzal kapcsolatban, hogy gyermekük részt vehet az olvasóköri foglalkozásokon!

\section{Az olvasókör megvalósitása}

2.1. Az 1. alkalom egy lehetséges időbeosztása (45 perces foglalkozást feltételezve):

0- 5. perc: a foglalkozás megnyitása, cél ismertetése

6-15. perc: a résztvevők bemutatkozása (név, viszonyulás az MI témához és az olvasáshoz), ismerkedési játékok alkalmazása.

16-30. perc: közös szabályok egyeztetése Például: kell-e hozni az aktuális mûvet? Közösen felolvasás jelleggel, közösen önálló néma olvasással, vagy házi feladatként történő olvasással történik-e egy műnek a megismerése? Ki mikor és mennyit szólhat hozzá a foglalkozáson kialakuló társalgáshoz, esetleg vitához? Egyeztetni célszerű a kulturált viselkedés, étkezés, foglalkozásra való érkezés és az arról való távozás szabályait, illetve a jelenléti ív vezetésének rendjét. Ne felejtsük el, hogy kiskorú résztvevők esetében a foglalkozást vezető felnőtt tartozik felelősséggel az olvasókör ideje alatt a gyerekekért!.

31-40. perc: a foglalkozásvezető felvezeti, bemutatja azokat a szerzőket és mûveiket, akikkel/amikkel az olvasókör tagjai megismerkednek.

41-45. perc: a következő foglalkozásig tartó időszakban elolvasandó mű(részlet) és/vagy feladat közlése, a foglalkozás zárása.
2.2. Az olvasókör közbülső (például: 214.) alkalmainak lehetséges időbeosztása (45 perces alkalmat feltételezve):

0- 5. perc: foglalkozás megnyitása, bemelegítő beszélgetés

6-15. perc: az olvasásra kiadott mû(részlet) felelevenítése vagy közös elolvasása (nyugodt tempóban jól olvasó felnőtt kb. 5-10 oldalt tud hangosan felolvasni a szöveg karakterszáma függvényében. Kezdő vagy rosszul olvasó tanulók/ felnőttek esetében 2-3 felolvasása várható ennyi idő alatt).

16-20. perc: a művel kapcsolatban kiadott házi feladatra érkezett megoldások megbeszélése vagy interaktív játékos gyakorlat végzése a művel kapcsolatban.

21-40. perc: véleménycsere, vita a művel kapcsolatban. Meghívott vendég (például: szerző, szakértő) bevonására is itt van lehetőség.

41-45. perc: a következő foglalkozásig tartó időszakban elolvasandó mű(részlet) és/vagy feladat közlése, a foglalkozás zárása.

2.3. Az olvasókör utolsó (például: 15.) alkalmának lehetséges időbeosztása (45 perces alkalmat feltételezve):

0- 5. perc: foglalkozás megnyitása, bemelegítő beszélgetés

6-15. perc: a foglalkozássorozat alatt az olvasásra kiadott mű(részlet)ek felelevenítése.

16-20. perc: a múvekkel kapcsolatos interaktív játékos gyakorlat végzése. 
21-40. perc: véleménycsere, vita a foglalkozássorozattal és a művekkel kapcsolatban.

41-45. perc: a foglalkozássorozat zárása.

\section{Az olvasókör utómunkálatai}

3.1. A foglalkozássorozaton szerzett tapasztalatok összegzése

3.2. A foglalkozássorozat tapasztalatainak publikálása. Javasolt Open Access folyó-iratok: OxIPO, Mesterséges intelligencia, Lélektani hadviselés. Ezek közös weboldala: www.kpluszf.com

\subsection{További olvasókörök előkészítése}

Az MI témával kapcsolatos attitűdök olvasókörök révén történő formálását a résztvevők egyéni vagy kiscsoportos formában történő (a foglalkozásokon vagy az azok közötti időszakban megvalósuló) adatgyüjtése és saját vélemény megfogalmazására késztetése is kísérheti. Az adatgyüjtés, illetve saját vélemény megfogalmazása feladatlapos formában is megvalósulhat.

\section{Példák olvasóköri feladatlapokra}

Az alábbiakban Isaac Asimov robot-történeteire épülő, az író $15+1$ novelláját feldolgozó feladatlap-sablont mutatunk be (1. ábra), amit a Kocka Kör Tehetséggondozó Kulturális Egyesület NTPINNOV-21-0241 projektje számára dolgozott ki e tanulmány szerzője. Természetesen más sci-fi írók is kiválóan megfelelnek az MI-vel kapcsolatos attitűdformálást célzó olvasókörök esetében.
Ugyanakkor Asimov megkerülhetetlen alakja a robotokkal kapcsolatos sci-fi irodalomnak, akinek írásait, gondolatait - különösen a robotika törvényeivel kapcsolatos felvetéseit - világszerte előszeretettel idézik nemcsak a sci-fi írók, hanem az MI téma kutató is. Robottörténetei magyar nyelven is elérhetők (lásd például: Asimov, 1993) - ezek közül választottunk ki a teljesség igénye nélkül 16-ot.

Egy iskolai félév 13-15 hétből áll, ami azt jelenti, hogy a 16 mú heti egyszeri találkozást és 1 novella/hét ritmusú olvasást feltételezve biztosan, rátartással is elég lehet egy féléves foglalkozássorozat esetében (ami attól függően, hogy egy-egy alkalom szimpla vagy dupla órákat jelent-e, $\mathrm{kb}$. 15-30 órás foglalkozássorozatnak felelhet meg).

Az Asimov által többnyire 1940-1975 között (tehát a II. világháború és a hidegháború idején) írt robot-történetekben az emberek védelmét a robotokba „gyárilag beépített" törvények szolgálják - ezek ismerete lényeges a novellák olvasóköri feldolgozása során!

Megjegyzés: a kulturális, és interkulturális, illetve nemzetközi aspektusok mindig fontos szerepet játszanak az irodalmi művek tágabb kontextusának megértése során. Szemléletes példát nyújt erre Bárczi (2020). Asimov robot-történeteiben például jellemzően (de nem mindig) az amerikai (értsd: USA-beli) robotok és humán szereplők jelennek meg, de sok esetben már Földön kívüli környezetben és/vagy a 


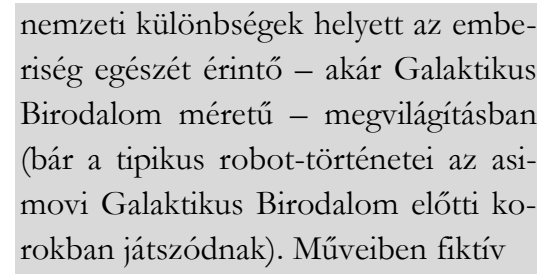

nemzeti különbségek helyett az emberiség egészét érintő - akár Galaktikus Birodalom méretű - megvilágításban (bár a tipikus robot-történetei az asimovi Galaktikus Birodalom elôtti korokan játszódnak). Múveiben fiktî

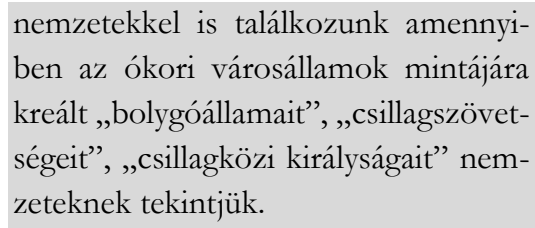
ben az ókori városállamok mintájára kreált „,bolygóállamait”, „,csillagszövetségeit”, „csillagközi királyságait” nemzeteknek tekintjük.

1. ábra: Isaac Asimov robot-történeteinek olvasóköri feldolgozásáboz használható feladatlap-sablon. A feladatlapot az olvasókör rész̨tvevöi töltik ki a foglalkozásvezetö által megadott források alapján. Forrás: a Szerzọ".

\section{"OROCKA KÖR \\ FELADATLAP \\ ISAAC ASIMOV ROBOTOKKAL KAPCSOLATOS TÖRTÉNETEIRE ÉPÜLŐ ISMERETTERJESZTŐ FOGLALKOZÁSOKHOZ}

A feladatlap kitöltője:

A mű szerzője: Isaac Asimov

A mü címe:

A mủ első megjelenésének éve:

Mikor játszódik a történet? Év:

A robot neve:

A robot meghibásodásának oka:

A robot meghibásodásának tünete:

Novellában szereplő megoldás:

Saját vélemény:

- A mü Asimov (1920-1992) életrajzának vonatkozásában:

- A mü kultúrtörténeti vonatkozásai (milyen történelmi eseményekre reflektálhatott az író a müben?):

- Fikció és/vagy valóság? Azzal kapcsolatos vélemény, hogy a mü játszódásának évében, illetve napjainkban mi valósul(ha)t meg a történetből:

- A mü etikai, jogi vonatkozásaival kapcsolatos vélemény:

- A mü gazdasági vonatkozásaival kapcsolatos vélemény:

- A mú informatikai, robotikai vonatkozásai:

- A robot meghibásodásának megelőzésével kapcsolatos lehetőségekről alkotott vélemény:

A feladatlapot összeállította: Dr. Mező Ferenc

$$
\text { Projekt: NTP-INNOV-21-0241 Támogatók: }
$$


Asimov világában a robotika törvényeinek a robotoknak meg kell felelni, különben működésképtelenné válnak. Novelláiban a robotok hibás mûködését legtöbb esetben e törvények közötti ellentmondások okozzák. Az Asimov által eredetileg megfogalmazott három törvény a következő:

Első törvény: a robotnak nem szabad kárt okoznia emberi lényben, vagy tétlenül tűrnie, hogy emberi lény bármilyen kárt szenvedjen.

Második törvény: a robot engedelmeskedni tartozik az emberi lények utasításainak, kivéve, ha ezek az utasítások az első törvény előírásaiba ütköznének.

Harmadik törvény: a robot köteles gondoskodni saját védelméről, amenynyiben ez nem ütközik az első vagy második törvény bármelyikének előírásaiba.

Megjegyzés: Asimov később bevezetett egy nulladik törvényt is, ami az emberiség érdekét állítja az egyes ember védelme, te-hát az első törvény elé.

Az 1. ábrán látható feladatlap-sablont az olvasókör résztvevői töltik ki a foglalkozásvezető instrukciói alapján. A feladatlap első része az adott műre vonatkozó adatok (például első megjelenés éve, a mű melyik évben játszódik, mi a neve a benne szereplő robotnak, stb.) gyüjtését, rendszerezését kéri a kitöltőjétől. A feladatok másik része pedig a kitöltőt arra ösztönzi, hogy fogalmazza meg saját véleményét, állásfoglalását a művel, illetve a felvetett szempontokkal kapcsolatba. E válaszok képezik az alapját a műről történő társalgásnak, vitának.

Az olvasókörbe bevont 16 novella alapadatai a következők (sorrend: az alapján, hogy mikor játszódik a történet):

\section{1. mü:}

- Szerző: Isaac Asimov

- A mú címe: Egy fiú legjobb barátja (A boy's best friend)

- A mú első megjelenésének éve: 1975

- Mikor játszódik a történet? Év: 1995

- A robot neve: Robogó (robotkutya, testőr)

- A robot meghibásodásának oka: nem hibásodik meg.

- A robot meghibásodásának tünete: nem hibásodik meg. De: Jimmy, a főhős kisfiú a robotkutyát választja az igazi helyett

- A múben szereplő megoldás: nincs.

2. mü:

- Szerző: Isaac Asimov

- A mú címe: Robbie (Robbie)

- A mű első megjelenésének éve: 1940

- Mikor játszódik a történet? Év: 1998

- A robot neve: Robbie (nőrsz) 
- A robot meghibásodásának oka: A robot tökéletesen működik, de az anya és a szomszédok félnek tôle.

- A robot meghibásodásának tünete: nincs tünet.

- A múben szereplő megoldás: A robotot eladják a szülők. A 8 éves Glória jobban szereti a robotot, mint egy kutyát. 15 éves korában visszaszerzi a robotot.

\section{3. $m и ̈:$}

- Szerző: Isaac Asimov

- A mú címe: Az AL-76 robot elkeveredik (Robot Al-76 Goes Astray)

- A mű első megjelenésének éve: 1942

- Mikor játszódik a történet? Év: 2006

- A robot neve: AL-76 (holdbéli bányamunkára tervezték)

- A robot meghibásodásának oka: a Hold helyett a Földre került, összezavarodott, „valami elpattant a robot agyában"

- A robot meghibásodásának tünete: Két zseblámpaelemmel is múködtethető eszközt (bányászati célra is használható és fegyvernek is alkalmas romboló eszközt) épített, és eltüntette vele egy domb felső részét.

- A műben szereplő megoldás: Meg akarják semmisíteni.

4. mü:

- Szerző: Isaac Asimov

- A mú címe: Logika (Reason)

- A mű első megjelenésének éve: 1941

- Mikor játszódik a történet? Év: 2015
- A robot neve: Zseni (ZSN-I., a Földre energiát sugárzó ûrállomás irányítására tervezték)

- A robot meghibásodásának oka: kognitív disszonancia, ami során az alábbi két ismeret ütközik egymással: 1) a robot tökéletesebb az embernél, 2) tökéletlenebb nem alkothat tökéletesebbet. Konklúzió: ZSN-I-t nem ember teremtette, hanem más. Ezen kívül a robotika 1 . és 2 . törvényének a konfliktusa is fennáll: 1. törvény: az ember védelme, 2. törvény: engedelmesség az embernek. De Zseni esetében a 2 . törvény felülírta az 1. törvényt, ezért a feladatokat tökéletesebben végrehajtani tudó robot kitiltotta a vezérlőfülkéből az embereket.

- A robot meghibásodásának tünete: Zseni nem hiszi el, hogy emberektôl származik, s az úrállomás energiakonverterét tekinti teremtőjének, s erről a többi robotot is meggyőzi. Sajátos vallást épít ki: Mester: energiakonverter. Próféta: Zseni. Hívek: többi robot. Emberek: kezdetleges teremtmények

- A műben szereplő megoldás: Mivel Zseni jól végzi dolgát, nem érdekli az embereket, miben hisz.

- Megjegyzés: a mú felveti az öntudattal rendelkező robotok, és ezek vallással, világnézettel kapcsolatos problémáit is.

\section{5. mü:}

- Szerző: Isaac Asimov

- A mú címe: Körbe-körbe (Runaround) 
- A mű első megjelenésének éve: 1941 1942

- Mikor játszódik a történet? Év: 2015

- A robot neve: Sebi (SB-13, Merkúrra tervezett humanoid robot)

- A robot meghibásodásának oka: kognitív disszonancia a robotika 2. törvénye („Hozz szelént!” parancs teljesítése) és az önvédelemről szóló, de Sebi esetében felerősített 3. törvény között, mert a szelén a robotra ártalmas helyen van, amitôl távolodni kell, ugyanakkor, ha nem szerez szelént, akkor az emberek meghalnak (az 1. törvény alapján ez nem elfogadható opció).

- A robot meghibásodásának tünete: Sebi a Merkúr felszínén a szelén lelőhely körül köröz, furcsán beszél, ha az emberek felé tartanak, fogócskázni kezd.

-A múben szereplő megoldás: Az 1. törvény (védelem) szerinti viselkedés provokálása: az emberek életveszélyt idéznek elő, aminek hatására megszűnnek Sebi tünetei és az emberek segítségére siet, így megszűnik a körbenforgás.

6. $m$ й:

- Szerző: Isaac Asimov

- A mú címe: Fogd meg a nyulat! (Catch that Rabbit)

- A mű első megjelenésének éve: 1944

- Mikor játszódik a történet? Év: 2016

- A robot neve: Dave (DV-5) több tagból álló irányító robot és az alárendelt hat másik segédrobot. Feladatuk: egy aszteroidán kell bányászniuk.
- A robot meghibásodásának oka: veszélyhelyzetben Dave túlterhelődik, és nem képes feladatát ellátni, nem képes a hat alárendelt robotot irányítani.

- A robot meghibásodásának tünete: a több tagú robot termelőmunkája leáll, ha nem figyelik, és a segédrobotok menetalakzatban masíroznak - ilyenkor Dave „malmozott az ujjaival”.

- A múben szereplő megoldás: az emberek kiiktatnak egy robotot a hat segédrobot közül, így kevesebb felé kellett figyelnie.

7. mü:

- Szerző: Isaac Asimov

- A mú címe: Te hazug! (Liar!)

- A mű első megjelenésének éve: 1941

- Mikor játszódik a történet? Év: 2021

- A robot neve: Herbie (HRB-34, gondolatolvasó robot)

- A robot meghibásodásának oka: gyártási hiba következtében gondolathullámokra tud hangolódni a robot. A robotika 1. törvénye értelmében az érzelmi/gondolati problémáktól is védeni kell az embert.

- A robot meghibásodásának tünete: Milton Ashe (az Amerikai Robot és Gépember Bt.) kutatója észrevette, hogy gondolati úton beszél hozzá a robot.

- A múben szereplő megoldás: egy robotpszichológus megoldhatatlan dilemma elé állította a robotot (ha elárul valamit, akkor sérelmet okoz, ha nem árul el, akkor is), amitől az lefagyott. 
- Megjegyzés: a gondolatolvasás VS. távközlés, neuroimplantok, gondolavezérelt műszervek, poszthumanizmus kérdéskörét is felvetheti a mú.

8. mü:

- Szerző: Isaac Asimov

- A mû címe: Tökéletes kiszolgálás! (Satisfaction Guaranteed)

- A mű első megjelenésének éve: 1951

- Mikor játszódik a történet? Év: 2023

- A robot neve: Tony (TN-3, háztartási munkát végző, szuperrealisztikus robot)

- A robot meghibásodásának oka: a robotika 1. törvénye az ember védelme, és Tony arra a következtetésre jut, hogy gazdáját is meg kell védeni a saját kisebbrendűségi érzetétől.

- A robot meghibásodásának tünete: három hét alatt a kezdetben gyúlölködő nő (a robot újdonsült gazdája) beleszeret a robotba, s látszólag a robot is viszonozza az érzéseket.

- A múben szereplő megoldás: a robotot eltávolítják, egyben elkezdődik a csábító robotok gyártása.

- Megjegyzés: a mû felvetheti az ember helyett robotszeretők választásának kérdést, illetve a szexrobotok témáját.

\section{9. $m u ̈:$}

- Szerző: Isaac Asimov

- A mú címe: Lenny (Lenny)

- A mű első megjelenésének éve: 1958

- Mikor játszódik a történet? Év: 2025
- A robot neve: Lenny (LNE, a kisbolygó övezetben lévő bórbányákba szánt robot)

- A robot meghibásodásának oka: egy gyárlátogatás alkalmával a 16 éves Mortimer W. Jakobson véletlenszerűen megnyomkodott néhány billentyűt a robot agyakat tervező számítógép konzolján. Charles Randow computertechnikus úgy tesz a robotnak, mintha meg akarná bokszolni azt.

- A robot meghibásodásának tünete: gügyögő, ujját szopó, járni kézen fogva tudó „csecsemő” mentalitású, munkaképtelen, de tanítható robot jött létre. A robotika 3. törvénye (= önvédelem) értelmében Lenny megütötte az őt megbokszolni igyekvő technikust, akinek eltört a karja (az 1. törvényt megsértette, de nem szándékosan: nem volt tisztában az erejével).

- A műben szereplő megoldás: a robotpszichológusnő, Susan Calvin, kísérleteket végez a robot taníthatóságával kapcsolatban (közben kiéli anyai ösztöneit: ember gyermek helyett ,,robotgyermeket" választ). Beindul a taintható robotok gyártása (szemben az addigi „célfeladatra” gyártott robotokkal.

- Megjegyzés: Asimov megemlíti a novellában a Frankenstein-komplexust (az ember fél a saját maga által létrehozott, erősebb teremtményétől). A Machine Learning, a gépi tanulás kutatása a való világban már 2025 (a történetben megjelölt évszám) előtt elkezdődik. 
10. mü:

- Szerző: Isaac Asimov

- A mû címe: Az eltűnt robot (Little Lost Robot)

- A mű első megjelenésének éve: 1947

- Mikor játszódik a történet? Év: 2029

- A robot neve: Nesztor-10 (NSZ-10, korlátozott 1. törvénnyel gyártott robot: szándékosan nem árthat az embernek, de nem muszáj megakadályoznia az ártalmat. Létrehozására azért volt szükség, mert a Hiper Bázison (egy aszteroidán) a hiperatom-hajtómú fejlesztése során gondot okozott, hogy a robotoktól nem tudtak dolgozni az emberek, amíg le nem korlátozták az 1. törvényt.

- A robot meghibásodásának oka: Gerald Black fizikus a robotot becsmérlő kifejezések mellett „Tünj el!” tartalmú parancsot adott, aminek a 2. törvény értelmében a robot engedelmeskedett. A robot megsértődött és bizonyítani akarta felsőbbrendűségét azzal, hogy a parancsot teljesítve valóban eltűnt. „Neurotikus szükséglet hajtja, mindenáron túl akar járni az emberek eszén."

- A robot meghibásodásának tünete: eltünt egy robot, pontosabban 62 hasonló kinézetű robot közé bújt 63.-ként. A robotoknak a titkos katonai kísérletekre tekintettel nincs azonosító száma, mindenre egyformán reagálnak.

- A múben szereplő megoldás: az első ötlet az, hogy semmisítsék meg mind a 63 robotot. Ez azonban nem praktikus, mer egy robot 30.000 dollárba kerül, s
63 robot $\mathrm{x} 30.000$ dollár $=\mathrm{kb}$. 2.000.000 dollár veszteséget jelent, ami túl nagy. Második ötlet: a robotika 1 . törvényét provokáló helyzetet hoznak létre (egy ember életveszélybe kerül), úgy, hogy a 3. törvényt (önvédelem) is provokálják: a robotok úgy tudják, hogy halálos gamma-sugárzást kapnak, ha megmentik az embert. Azt a parancsot kapták (v.ö.: 2. törvény), hogy ha nem tudják megmenteni az embert, akkor ne áldozzák fel saját magukat (v.ö.: 3. törvény). A NSZ-10 kivételével a robotok nem tudtak különbséget tenni a különböző sugárzások között, így a rájuk nézve ártalmatlan infrasugárzást is pusztítónak vélték és nem mozdultak, míg NSZ-10 ugrott, hogy megmentse az embert, mert tudta, hogy nem pusztító sugárzásban fog részesülni. NSZ-10 egy a szemében alacsonyabb rendű embertől tanulta meg a gamma sugárzást megkülönböztetni a többitől, és nem akart rá emlékezni, hogy a többi robot butább, mint az ember.

- Megjegyzés: felsőbbrendűségi és a kisebbrendűségi komplexus témája is felmerülhet a mű kapcsán.

11. mü:

- Szerző: Isaac Asimov

- A mú címe: A csillagokba! (Escape!)

- A mű első megjelenésének éve: 1945

- Mikor játszódik a történet? Év: 2031

- A robot neve: Agy 
- A robot meghibásodásának oka: kognitív disszonancia. A robotika emberek védelmére vonatkozó 1 . törvénye miatt nem hajlandó embert veszélyeztető problémamegoldást végezni az Agy, tekintve, hogy a tôle elvárt kozmikus ugrás halálos. De: az engedelmességre vonatkozó 2. törvény ilyen probléma megoldására kötelezi. A feszültséget nevetgéléssel, humorral kompenzálta az Agy.

- A robot meghibásodásának tünete: várható a lefagyás vagy egyéb üzemzavar. Az Agy csillagközi űrhajót épített, s engedély nélkül elindította a fedélzetén két emberrel, és távvezérléssel irányítja a hajót. Az agy hisztérikus tüneteket mutat (nevetgél), amikor a hiperűrugrásról és az utasok biztonságáról faggatják.

- A múben szereplő megoldás: Agy rájön, hogy hiperűrugráskor meghalnak ugyan az emberek, de visszatérnek, amint a hajó is visszatér a hiperűrből. Ez a „halál” tehát átmeneti jelenség.

- Megjegyzés: a mű kapcsán felmerülhet az „egy robot fejtette meg a csillagközi ugrás problémáját, s okozott gazdasági stabilitást a Földön" témaköre is. Okosabb lehet-e a robot, mint az ember?

\section{2. mü:}

- Szerző: Isaac Asimov

- A mú címe: A kockázat (Risk)

- A mú első megjelenésének éve: 1955

- Mikor játszódik a történet? Év: 2031
- A robot neve: a hiperűrugrás kísérleti járművét, a Parsec űrhajót irányító robot

- A robot meghibásodásának oka: a Parsecet vezetô robot parancsba kapta, hogy indításkor erősen húzza maga felé az irányító kart. A robot túl erősen húzta meg a kart, ami elromlott és az űrhajó nem indult el.

- A robot meghibásodásának tünete: nem indítja el a robot az űrhajót.

- A múben szereplő megoldás: helyesen kell kiadni a parancsot.

- Megjegyzés: a múben szereplő kutatók a robot létét fontosabbaknak tartják, mint az emberekét, akik feláldozhatók. A robotok biztonságát választják az embereké helyett - ez lehetőséget biztosíthat etikai, jogi dilemmák megvitatására egy foglalkozás során.

\section{3. mü:}

- Szerző: Isaac Asimov

- A mú címe: Bizonyíték (Evidence)

- A mű első megjelenésének éve: 1946

- Mikor játszódik a történet? Év: 2032

- A robot neve: Stephen Byerley

- A robot meghibásodásának oka: Stephen Byerley autóbalesetet szenvedett, lábait elvesztette. Épített egy robotot, aki helyettesítette őt az életben.

- A robot meghibásodásának tünete: Byerley államügyészt senki sem látta még enni, inni, aludni. Politikai ellenfele, Francis Quinn, ezt használja ki, s híreszteli el, hogy Byerley robot. 
-A múben szereplő megoldás: Byerley egyen nyilvánosan - ez nem kihívás a múben. Byerley üssön meg valakit (tekintve, hogy egy robot erre az 1 . törvény értelmében képtelen): a robot Byerley ezt nyilvánosan megtette. Amit a nyilvánosság nem tudott: akit megütött az valójában emberszerű robot volt, akire nem vonatkozik a robotika 1 . törvényének tiltása.

- Megjegyzés: Byerley politikai karriert csinált Asimov műveiben: 2032-ben polgármesterré választják. 2044-ben a Föld régiói által létrehozott Föderáció első világkoordinátora lett. 2052-ben már második világkoordinátori ciklusa vége felé jár. „Pályaválasztásának” oka: a robotika három törvénye az emberi erkölcs alapjaira épül, akár a felelősen végzett politika. Ez lehetővé teszi, hogy akár a pályaválasztás, akár a robot/ember politikus preferálásának kérdése irányába tereljük a beszélgetést.

14. mü:

- Szerző: Isaac Asimov

- A mú címe: Rabszolga (Galley Slave)

- A mű első megjelenésének éve: 1957

- Mikor játszódik a történet? Év: 2034

- A robot neve: Izé, EZ-27 $(210$ cm magas szövegkorrektor robot, nemcsak a fizikai, hanem a szellemi munkát is elvégzi)

- A robot meghibásodásának oka: Ninheimer nevű szereplő utálta a robotot, mert úgy vélte, hogy elveszi a szellemi munkát az embertől, s ezért szándékosan rossz szöveget adatott ki a robottal, s azt parancsolta neki (2. törvény), hogy erről hallgasson, különben Ninheimer kárt szenved (ez az 1. törvény értelmében megengedhetetlen).

- A robot meghibásodásának tünete: Simon Ninheimer professzor 750.000 dolláros kártérítési pert indít az Izét gyártó Amerikai Robot és Gépember Rt. ellen. Állítása szerint a korrektor robot önkényesen finomítja a cikkek állításait, nehogy kárt szenvedjenek azok alanyai (v.ö.: 1. törvény). Ennek következtében a szerzők tudományos hitele, híre csökken.

- A műben szereplő megoldás: a robotpszichológus szerint Ninheimer hazudik, mert a robot nem képes olyasmire, amit neki tulajdonítanak. A robotpszichológus olyan mondatokat mondatott ki a robottal, hogy Ninheimer azt hitte a robot elárulta ôt, s Ninheimer elszólta magát (önmagát leplezte le): „...nem megmondtam, hogy ki ne nyisd a szád...?” kiáltott a robotra.

\section{5. mü:}

- Szerző: Isaac Asimov

- A mú címe: Az első törvény (First Law)

- A mú első megjelenésének éve: 1956

- Mikor játszódik a történet? Év: 2035

- A robot neve: Emma-2 (MA-2, a Titánra szerkesztett robot, mely nem engedelmeskedett az első törvénynek) 
- A robot meghibásodásának oka: MA-2 létrehozta Emma Juniort, s anyaként védelmezte azt.

- A robot meghibásodásának tünete: elkóborolt, mindenfelé, elbújt a bálák alá, s úgy kellett előcsalogatni. Végül elkószált a támaszpontról és egyáltalán nem jött vissza. Viharban nem az embert mentette, hanem a „robot bébit”.

- A múben szereplő megoldás: Az MA sorozatot azonnal kivonták a forgalomból.

- Megjegyzés: a „lehet-e egy robotnak érzelme" kérdés és a gépek önálló reprodukciójának témaköre egyaránt felvetődhet a mű kapcsán.

16. mü:

- Szerző: Isaac Asimov

- A mú címe: Elkerülhető konfliktus (The Evitable Conflict)

- A mű első megjelenésének éve: 1950

- Mikor játszódik a történet? Év: 2052

- A robot neve: Gépek (a Föld gazdaságát a robotika törvényei alapján irányító gépek, melyek olyan bonyolultan múködnek, hogy kiszakadtak az emberi ellenőrzés lehetősége alól).

- A robot meghibásodásának oka: a Gépek megbízhatók, a kiinduló adatok rendben vannak. Az engedetlenség kizárt, hiba nincs. Ok: a Gépek elmozdítják az ellenük (így az emberiség érdeke ellen!) lévő vezető beosztású embereket (az Emberiségvédő Társaság kis létszámú, de nagy hatalmú tagjait).
- A robot meghibásodásának tünete: Alul-/túltermelés mutatkozik: hibáznak a gépek, csődhelyzetek alakulnak ki.

- A műben szereplő megoldás: Stephen Byerley világkoordinátor Susan Calvin robotpszichológustól kér segítséget, aki rájön, hogy a Gépek módosították az 1. törvényt: nem az emberért, hanem az emberiségért dolgoznak.

- Megjegyzés: az egyén VS. csoport, egyén VS. emberiség léptékében történő gondolkodás felé terelhetők a mû által az olvasókör tagjai.

\section{Zárógondolatok}

A mesterséges intelligenciával kapcsolatos attitűdök a szélesebb közönséget tekintve a film- és olvasmány élményeken keresztül nyerik „tudásbázisukat”.

Megjegyzés: noha napjainkban többnyire a képernyő előtt nőnek fel az új generációk (v.ö.: Nagyová Lehocká, 2018), semmint a hagyományos könyveket olvasva, azért a filmek szélesebb nézőközönsége mellett, illetve azon belül, még mindig van egy komoly olvasó réteg is. Sőt: az olvasóvá nevelés szempontjából a mesterséges intelligenciáról szóló sci-fi irodalmak ajánlása akár hatékony eszköz is lehet!

Természetesen a fikciós történetek sajátja, hogy az Olvasó érdeklődését drámai, nemegyszer (akár a realitástól nagyon is 
elrugaszkodó) tragikus helyzetek megteremtésével igyekszik előidézni, amiben a mesterséges intelligencia a következő szerepeket kaphatja az írótól, forgatókönyv írótól (a példákban az emberi befogadók esetében azt feltételezzük, hogy nincsenek emberellenes késztetéseik, az MI-k esetében pedig azt, hogy lényegtelen, hogy létezhet-e szándék az MI esetében, hiszen egy fikciós műben minden lehetséges):

1. Az MI szándékosan emberellenes gondolatokat fogalmaz meg, cselekvéseket hajt végre. Várható következmény: a befogadó emberben negatív attitűd marad a „gonosz” MI-vel kapcsolatban.

2. Az MI nem szándékosan fogalmaz meg emberellenes gondolatokat, nem szándékosan, de árt az embernek. A befogadó emberben az szintén negatív attitűdöt erősíthet meg a ,veszélyes” MIvel kapcsolatban.

3. Az MI semleges szerepet játszik a műben szereplő emberek életével kapcsolatban. Ez a „csak egy bútordarab, semmi érdekes" jellegű semleges beállítódást erôsíthet meg a befogadó emberekben az MI-vel kapcsolatban, illetve az MI-rôl kapott új információ a korábbi negatív vagy pozitív jellegű attitűdnek nem mond ellent.

4. Az MI nem szándékosan fogalmaz meg, hajt végre embert/emberiséget segítő gondolatokat, tetteket. A mú által nyújtott tapasztalat az MI-vel kapcsolatos pozitív „Nicsak, milyen hasznos!” jellegű attitűd kialakulásának kedvez az emberi befogadóban.

5. Az MI szándékosan embert/emberiséget támogató gondolatokat fogalmaz meg, ilyen tetteket hajt végre. Ez az „MI az ember legjobb barátja” sarkított állítással jellemezhető pozitív attitűdnek kedvez a befogadó emberekben.

A felvetett öt szereplehetôség sajátja, hogy noha önmagában egyik sem képviselheti a valóságot, mégis hatással lehet az MI-vel kapcsolatos attitűdök alakulására. Fontos: a film- és olvasmányélményeken keresztül történő attitűdformálás olyanok körében is jellemző lehet (és most valóban tömegekről, több milliárd emberről van szó!) akik, nem szakértői az MI témának, és talán más információforrásuk nincs is az MI témáról, ugyanakkor választó joggal rendelkeznek a demokratikus társadalmakban, illetve vásárlóerővel bírnak a (demokráciát természetesen nem kizáró) fogyasztói társadalmakban. A filmklubok és olvasókörök éppen ezért hasznos eszközei lehetnek az MI-vel kapcsolatos szemléletformálásnak.

Az MI-vel kapcsolatos attitűdformálás legkevésbé manipulatív, egyben etikailag a leginkább vállalható verziója, hogy az MI-t nem egyoldalúan jónak vagy rossznak állítjuk be, hanem a benne rejlő lehetőségeket és veszélyeket egyaránt felvetjük. A filmklubok és olvasókörök nemcsak az adott mûvet mutathatják be, hanem az 
arról szóló beszélgetések, viták révén árnyaltabb képet adhatnak a mesterséges intelligenciáról, mint ami egy-egy múben egyáltalán közvetítésre kerülhet.

\section{Irodalom}

Allport, G. W. (1954). The nature of prejudice. Cambridge, Mass.: AddisonWesley Publishing Company

Asimov, Isaac (1993): Robottörténetek 1-2.

Móra Ferenc Könyvkiadó, Budapest.

Bancsi Zoltán és Mező Katalin (2020). A színházpedagógia és a fejlesztőpedagógia kapcsolódási pontjai. OxIPO - interdiszciplináris tudományos folyóirat, 2020/4, 23-39. doi: 10.35405/OXIPO.2020.4.23

Bárczi, Zsófia (2020): Attempts at creating a new concept of literature (The Hungarian literature in Slovakia between the two world wars). Hungarian Studies, 34 (2020) 1, 7-14. DOI $\underline{10.1556 / 044.2020 .00002}$

Beták Norbert és Szabó Tibor (2020). Térszemlélet-fejlesztést segítő foglalkozások Lego eszközök segítségével. OxIPO - interdiszciplináris tudományos folyóirat, 2020/4, 71-81. doi: 10.35405/OXIPO.2020.4.71

Csernai Zoltán (2020): Egy robotprogramozás szakkör munkatervének bemutatása. Mesterséges intelligencia - interdiszciplináris folyóirat, II. évf. 2020/2. szám. 45-52. doi: 10.35406/MI.2020.2.45

Mező Ferenc, Mező Katalin és Mező Kristóf Szíriusz (2019): Filmklubok szerepe a mesterséges intelligenciával kapcsolatos attitűdök formálásában. Mesterséges intelligencia - interdiszciplináris folyóirat, I. évf. 2019/1. szám. 67-94. doi: $\underline{10.35406 / \text { MI.2019.1.67 }}$

Mező Katalin (2015): Kreativitás és élménypedagógia. Kocka Kör, Debrecen.

Mező Katalin és Szabóné Burik Erika (2021): A robotokkal történő oktatás, az élménypedagógia aspektusából. Mesterséges intelligencia - interdiszciplináris folyóirat, III. évf. 2021/2. szám. 19-32. doi: $10.35406 /$ MI.2021.2.19

Mező Katalin és Mező Ferenc (2020): A múzeumpedagógia és a tehetséggondozás lehetôségei egy virtuális múzeumban. Különleges Bánásmód, 6. (3). 89-99. DOI $\underline{10.18458 / K B .2020 .3 .89}$

Nagy Lehocky Zsuzsa (2008): A tanulói érdéklődés felkeltésének fontossága. In: Bárczi Zsófia, Psenák Ildikó és Vančo Ildikó (szerk.): Képzés és gyakorlat = Edukácia a prax (tanulmánykötet). Nitra: UKF. 33-37. ISBN 978-80-8094427-8

Nagyová Lehocká, Zuzana (2018): Képernyő előtt felnőni. Katedra Szlovákiai magyar pedagógusok és szülök lapja (ISSN 1335-6445), Roč. 25, č. 5 (2018), p. 15-16.

Szabóné Balogh Ágota (2020): Kognitív képességek informatikai alapú fejlesztésének hatásvizsgálata 5-8. évfolyamon tanulók körében. OxIPO interdiszciplináris tudományos folyóirat, 2020/4, 41-58. doi: 10.35405/OXIPO.2020.4.41 
Tóth Attila, Nagy Lehocky Zsuzsa, Csáky Antal és Sedlák Margaréta (2021): Geometriai vizualizáció a gyakorlatban. OxIPO - interdiszciplináris tudományos folyoirat, 2021/1, 83-95. doi: $\underline{10.35405 / O X I P O .2021 .1 .83}$ 